\title{
Performance of Caponized Local Chicken under Different Production Systems for Small Scale Production in Resource Poor Settings
}

\author{
Bitupon Dutta, Raj Jyoti Deka*, Amulya Kumar Gogoi, Bibeka Nanda Saikia, \\ Jog Dev Mahanta, Saurabh Kumar Laskar and Chinmoy Dutta \\ College of Veterinary Science, Assam Agricultural University Khanapara, \\ Guwahati, Assam, India \\ *Corresponding author
}

\begin{abstract}
A B S T R A C T
Keywords

Capon, Intensive management, Local chicken

Article Info

Accepted:

07 September 2020

Available Online:

10 October 2020

To explore the productivity of caponized local chicken, an experiment was carried out with thirty (30) numbers of healthy caponized local chicken cockerels of Assam of about 7-8 months of age ( $210 \pm 10$ days) for a period of six months. The capons were randomly divided into three groups $\left(T_{1}, T_{2}\right.$ and $\left.T_{3}\right)$ of ten numbers each. One nutritional treatment was adopted for two groups $\left(T_{2}\right.$ and $\left.T_{3}\right)$ with formulated grower ration of poultry (CP $16.41 \%$ and ME $2650 \mathrm{Kcal} / \mathrm{kg}$ ). The control group $\left(\mathrm{T}_{1}\right)$ was reared in backyard condition with minimum supplementary feed. The average fortnightly change in body weight of capons of $\mathrm{T}_{3}$ was found to be significantly higher than $T_{2}$ and $T_{1}$ after 6 months of experimental period. The body weight gain was significant $(\mathrm{P}<0.05)$ between $\mathrm{T}_{3}$ and $\mathrm{T}_{1}$ as well as $\mathrm{T}_{2}$ and $\mathrm{T}_{1}$. The feed conversion efficiency of capons was more in cage system $\left(\mathrm{T}_{3}\right)$.
\end{abstract}

\section{Introduction}

Poultry farming in India is considered to be the techno-commercial industry which has been transformed from the status of backyard farming since last few decades and India occupying the third position in egg production and fifth position in chicken meat production in the World. According to $19^{\text {th }}$ livestock census of India, poultry population of India was estimated as 729.21 million with 82.93 billion eggs and 3.26 million tones of chicken meat production. This production has been generally achieved by commercial poultry operation; however, a significant contribution is generated from rural poultry also. Though major share of the poultry products come from commercially reared improved breed of birds, the source of indigenous poultry eggs and meat are always appreciated for their taste and texture in both rural and organized markets.

Capons are male chickens whose testes have been surgically removed through the process of caponization. The practice of caponization is very old, with records indicating that it was performed more than 2000 years ago, as mentioned by Aristotle in his Naturalis Historia. In the renaissance, the capon had its 
great splendor since it was the preferred food of the lords. Although superseded by modern broiler production, the caponization practice still survives today.

The rearing and marketing of capons, a traditional culture, is restricted only to the Tribal and Adivasi communities of Assam. They used to rear the caponized indigenous chicken traditionally with no supplemented feed in the backyard for holy purposes. No recordable experiment has been found to be undertaken scientifically on production potentiality of rearing indigenous chicken cockerels till today even at national level.

\section{Materials and Methods}

Thirty (30) numbers of caponized local chicken cockerels of Assam of about 7-8 months of age and apparently in similar weight were used for the experiment. The cockerels were randomly divided into three (3) groups of ten (10) birds in each group, i.e. $\mathrm{T}_{1}, \mathrm{~T}_{2}$ and $\mathrm{T}_{3}$. The cockerels of $\mathrm{T}_{1}$ group were reared as control without any treatment in backyard field condition. The cockerels of $\mathrm{T}_{2}$ and $\mathrm{T}_{3}$ groups were housed in deep litter and individual cage system of management respectively. The birds were put in well ventilated, clean and dry cages made of metallic wire of $18 \times 14 \times 20$ inch sizes having a metallic tray for collection of faecal materials at the bottom. In the deep litter system of management paddy, husk was used as a bedding materials and rotation of the litter material was done at weekly interval to prevent growth of any diseased producing organism. Proper and scientific measures were under taken to maintain hygiene and sanitation in the experimental site. The selected birds were dewormed prior to commencement of the experiment; faecal examination was carried out at regular intervals to ensure soundness of the birds. The birds of $\mathrm{T}_{2}$ and $\mathrm{T}_{3}$ were fed ad lib grower ration with a dietary energy level of 2650 $\mathrm{Kcal} \mathrm{ME} / \mathrm{kg}$ and 16 per cent $\mathrm{CP}$ for a period of 6 months with continuous clean drinking water flow.

The initial body weight of the experimental birds were recorded at the time of receiving the birds at experimental site and fortnightly body weights and body weight gain were recorded for 6 months. The data obtained in the study were analyzed statistically using GLM procedure of SAS Enterprise Guide 4.2.

\section{Results and Discussion}

\section{Body weight and body weight gain}

There was a gradual increase in body weight of capons in all three groups as the age of capons advanced (Table 1). The initial and final body weight of capons in $\mathrm{T}_{1}, \mathrm{~T}_{2}$ and $\mathrm{T}_{3}$ were recorded as $0.922 \pm 0.002$ and $1.364 \pm$ $0.039,0.921 \pm 0.001$ and $1.769 \pm 0.047,0.922$ \pm 0.002 and $1.902 \pm 0.033 \mathrm{~kg}$ respectively. The average fortnightly change in body weight of capons of $T_{3}$ was found to be significantly higher than $T_{2}$ and $T_{1}$ after 6 months of experimental period.

The body weight gain of the capons in $\mathrm{T}_{1}, \mathrm{~T}_{2}$ and $\mathrm{T}_{3}$ were recorded as $0.442 \pm 0.04,0.848 \pm$ 0.03 and $0.980 \pm 0.04 \mathrm{~kg}$ respectively. The highest total body weight gain of capons has been recorded in $T_{3}$ group reared under cage system of management. The body weight gain was significant $(\mathrm{P}<0.05)$ between $\mathrm{T}_{3}$ and $\mathrm{T}_{1}$ as well as $T_{2}$ and $T_{1}$.

The present findings in regards to fortnightly body weight change and body weight gain are almost in agreement with the findings of Chatterjee et al., (2002) and Rahman et al., (2004) who reported significantly increased body weight gain in caponized birds compared to non-caponized birds $(\mathrm{p}<0.01)$ (Fig. 1 and 2). 
Table.1 Average fort nightly changes in body weight $(\mathrm{kg})$ of capons under different treatments

\begin{tabular}{|c|c|c|c|c|}
\hline Fortnights & $\mathbf{T}_{\mathbf{1}}$ & $\mathbf{T}_{\mathbf{2}}$ & $\mathbf{T}_{\mathbf{3}}$ & $\mathbf{P}$-value \\
\hline Initial & $0.922 \pm 0.002$ & $0.921 \pm 0.001$ & $0.922 \pm 0.002$ & $0.0662^{\mathrm{NS}}$ \\
\hline $\mathbf{1}$ & $0.925 \pm 0.008$ & $0.926 \pm 0.024$ & $0.928 \pm 0.040$ & $0.0603^{\mathrm{NS}}$ \\
\hline $\mathbf{2}$ & $0.927 \pm 0.016$ & $0.938 \pm 0.023$ & $0.944 \pm 0.040$ & $0.1195^{\mathrm{NS}}$ \\
\hline $\mathbf{3}$ & $0.929 \pm 0.015$ & $0.970 \pm 0.023$ & $0.969 \pm 0.041$ & $0.1649^{\mathrm{NS}}$ \\
\hline $\mathbf{4}$ & $0.969 \pm 0.017$ & $1.001 \pm 0.021$ & $1.020 \pm 0.042$ & $0.1622^{\mathrm{NS}}$ \\
\hline $\mathbf{5}$ & $1.010 \pm 0.019$ & $1.055 \pm 0.023$ & $1.077 \pm 0.042$ & $0.0976^{\mathrm{NS}}$ \\
\hline $\mathbf{6}$ & $1.055 \pm 0.021^{\mathrm{b}}$ & $1.103 \pm 0.023^{\mathrm{ab}}$ & $1.145 \pm 0.043^{\mathrm{a}}$ & $0.0327^{*}$ \\
\hline $\mathbf{7}$ & $1.102 \pm 0.024^{\mathrm{b}}$ & $1.218 \pm 0.027^{\mathrm{a}}$ & $1.255 \pm 0.044^{\mathrm{a}}$ & $0.0082^{* *}$ \\
\hline $\mathbf{8}$ & $1.149 \pm 0.027^{\mathrm{b}}$ & $1.384 \pm 0.032^{\mathrm{a}}$ & $1.345 \pm 0.044^{\mathrm{a}}$ & $<.0001^{* *}$ \\
\hline $\mathbf{9}$ & $1.197 \pm 0.031^{\mathrm{b}}$ & $1.497 \pm 0.042^{\mathrm{a}}$ & $1.441 \pm 0.045^{\mathrm{a}}$ & $0.0234^{*}$ \\
\hline $\mathbf{1 0}$ & $1.252 \pm 0.034^{\mathrm{b}}$ & $1.580 \pm 0.033^{\mathrm{a}}$ & $1.553 \pm 0.043^{\mathrm{a}}$ & $<.0001^{* *}$ \\
\hline $\mathbf{1 1}$ & $1.308 \pm 0.038^{\mathrm{b}}$ & $1.658 \pm 0.046^{\mathrm{a}}$ & $1.676 \pm 0.042^{\mathrm{a}}$ & $<.0001^{* *}$ \\
\hline $\mathbf{1 2}$ & $1.364 \pm 0.039^{\mathrm{c}}$ & $1.769 \pm 0.047^{\mathrm{b}}$ & $1.902 \pm 0.033^{\mathrm{a}}$ & $<.0001^{* *}$ \\
\hline
\end{tabular}

Mean with different superscripts differ significantly

$*$ = Significant, $* *=$ Highly significant, NS = Not significant

Fig.1 Average fortnightly changes in body weight $(\mathrm{kg})$ of capons under different treatments

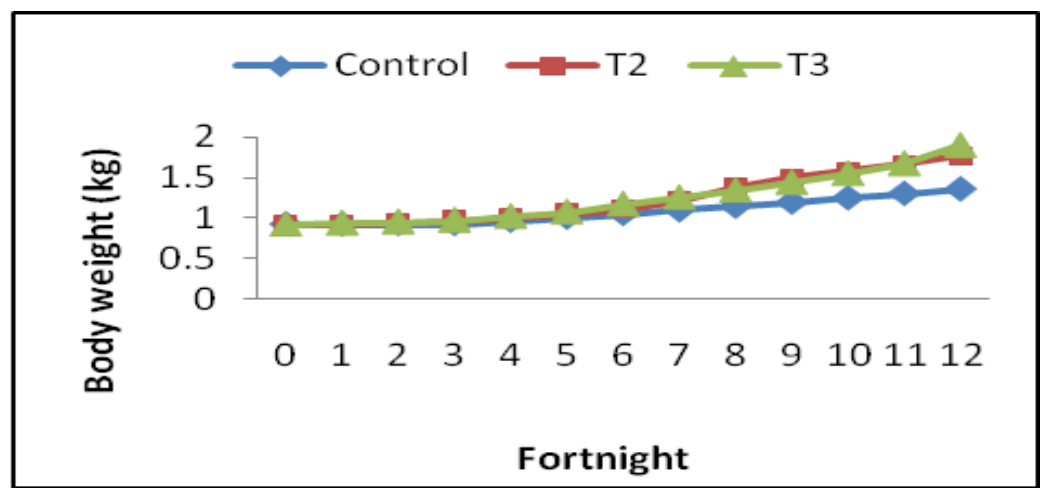

Fig.2 Total body weight gain $(\mathrm{kg})$ of capons under different treatments

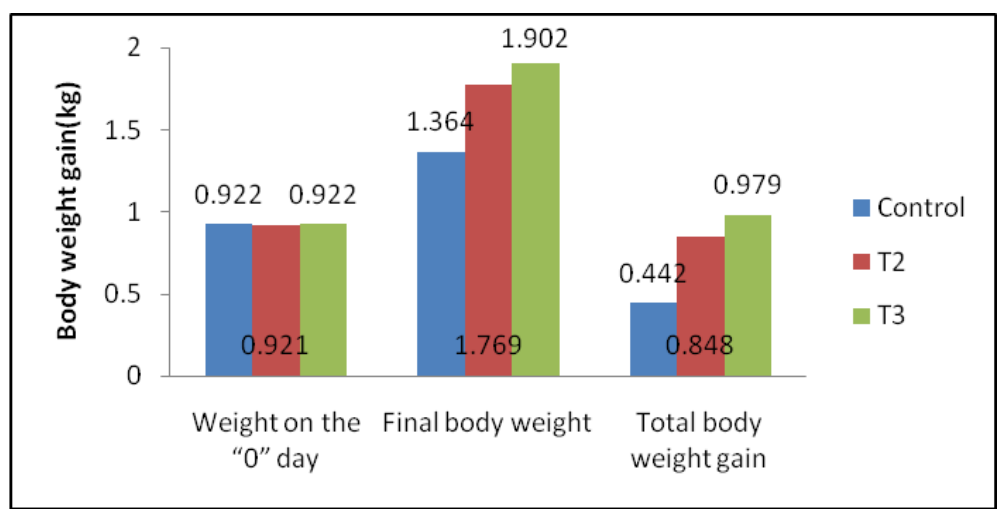


Chen et al., (2006) reported much lower weight gain in caponized Taiwan country chicken cockerels, Shao et al., (2009) in caponised male Tibetan chicken, Symeon et al., (2010) in caponized medium growth broilers and Calik (2014) in caponized chicken cockerels. However, Mahmud et al., (2013) reported significant differences $(p \leq 0.05)$ in mean final body weight of cockerel chickens but mean weekly weight gain, feed consumption and FCR did not differ significantly $(p \geq 0.05)$. The present findings are not in agreement with the findings of Bilal et al., (2014) who stated better body weight, feed intake and FCR in birds reared under floor compared to cage system. The differences in total and fortnightly body weight gain of capons were primarily due to nutritional status and different systems of management.

\section{Feed conversion ratio}

The mean FCR of capons in $\mathrm{T}_{2}$ and $\mathrm{T}_{3}$ groups during the experimental period of six months were found to be 8.43: 1 and 12.38:1 respectively.

The feed conversion efficiency of capons was more in cage system $\left(\mathrm{T}_{3}\right)$ compared to deep litter system of management $\left(\mathrm{T}_{2}\right)$. The feed conversion efficiency of capons was found to be better in $\mathrm{T}_{2}$ group under deep litter system though the total mean monthly feed intake and fortnightly body weight gain of capons in $\mathrm{T}_{3}$ group were found to be higher under cage system.

The present findings are in close agreement with the findings of Khaksefidi and Rahimi (2005) in broiler chicken, Ali et al., (2005) in native chicken of Bangladesh, Haunshi et al., (2009) in indigenous and improved varieties of chicken in northeastern region of India, and Calik et al., (2017) in Rhode Island Red (R11) capons.
In conclusion the study revealed that capons in cage system gained higher body weight in comparison to deep litter and extensive system of management. The feed conversion efficiency of capons was better (8.43:1) in deep litter compared to cage system of management (12.38:1) indicating economical feeding in deep litter system. Being indigenous in nature, capons were observed to be more comfortable in deep litter with slightly higher net return per capon compared to cage system of management.

The indigenous capons reared under intensive system of management with ad lib concentrate feeding $(2650 \mathrm{kcal} / \mathrm{kg} \mathrm{ME}$ and $16.41 \% \mathrm{CP}$ ) and supply of clean drinking water witnessed higher growth rate with better net returns.

From the present study it may be concluded that the intensive rearing of indigenous capons can generate sustainable income opportunities under small scale production system in resource poor settings under intensive system of management.

\section{Acknowledgement}

The authors are thankful to the Department of Livestock Production and Management, College of Veterinary Science, Assam Agricultural University, Khanapara-781022 for giving necessary permission and facility to carry out the research work.

\section{Conflict of interest}

There is no conflict between the authors regarding the preparation of the manuscript. The research was carried out as a part of fulfillment of M.V.Sc. Degree Programme. All authors contributed to the research woks and members of the research advisory committee. All authors read and approved the final manuscript. 


\section{Ethics approval}

The research was carried out according to the guidelines of Institutional Animal Ethics Committee of Assam Agricultural University, Khanapara, Guwahati-781022 as per the ethics application approval number 770/ac/CPCSEA/FVSc/AAU/IAEC/1617/471 dated 30.07.2016.

\section{References}

Ali, M.I., Azmal, S. A., Ali, A. and Faruque, M. O. (2005). Effect of density and flock size on growth performance of native Chicken. Journal of Bangladesh Agricultural University, 10 (1): 55 - 59

Bilal, K., Mahmood, S., Akram, M., Imran, S., Sahota, A.W., Hussain, J. and Ashfaq, A. (2014). Growth performance of broiler under two rearing systems in three different housing zones in an environmentally controlled house during winter. Journal of Animal \& Plant Science, 24 (4): $1039-1044$

Bouvarel, I., Chagneau, A. M., Lecuelle, S. and Leterrier, C. (2009). Feed composition and hardness interact in preference and intake in chickens. Applied Animal Behaviour Science, 118: $62-68$

Calik, J., Krawczyk, J., Świątkiewicz, S., Gąsior, R., Wojtycza, K., Połtowicz, K., Obrzut, J. and Puchała, M. (2017). Comparison of the physicochemical and sensory characteristics of Rhode Island Red (R-11) capons and cockerels. Annals of Animal Science, DOI: 10.1515/aoas-2017: 0002

Calik, J. (2014). CAPON production breeding stock, rooster castration and rearing methods, and meat quality - a review. Annals of Animal Science, 4: $769-777$

Chatterjee, R. N., Ahlawat, S. P. S., Yadav, S.
P., Senani, S., Kunder, A., Jeyakumar, S., Saha, S. K., Sunder, J. and Bharati, D. (2002). Comparative growth performance of Nicobari fowl and their cost effectiveness under backyard and intensive systems. Indian Journal of Poultry Science, 37 (1): 63 - 66

Chehraghi, M., Zakeri, A. and Taghinejad, R. M. (2013). Effects of different feed forms on performance in broiler chickens. European Journal of Experimental Biology, 3 (4): 66 - 70

Chen, K. L., Hsieh, T. Y. and Chiou, P. W. S. (2006). Caponization effects on growth performance and lipid metabolism in Taiwan country chicken cockerels. Asian-Australian Journal of Animal Science 19 (3): 438 - 443

Haunshi, S., Doley, S. and Shakuntala, I. (2009). Production performance of indigenous chicken of northeastern region and improved varieties developed for backyard farming. Indian Journal of Animal Science, 79 (9): 901 $-905$

Khaksefidi, A. and Rahimi, Sh. (2005). Effect of probiotic inclusion in the diet of broiler chickens on performance, feed efficiency and carcass quality. AsianAustralian Journal of Animal Science, 18 (8): 1153 - 1156

Mahmud, M. A. Shaba, P., Gana, J., Yisa, H.Y., Ndagimba, R. (2013). Effect of surgical caponisation on growth, carcass and some haematological parameters in cockerel chickens. Sokoto Journal of Veterinary Science, 11 (2): $57-62$

May, J. D., Lott, B. D. and Simmons, J. D. (1997). Water consumption by broilers in high cyclic temperatures: bell versus nipple waterers. Journal of Poultry Science, 76: 944 - 947

Quilumba, C., Quijia, E., Gernat, A., Murillo, G. and Grimes, J. (2015). Evaluation of different water flow rates of nipple 
drinkers on broiler productivity. Journal of Appllied Poultry Research, 24: $58-65$

Rahman, M. M., Islam, M. A., Ali, M.Y., Khondaker, M. E. A. and Hossain, M. M. (2004). Effect of caponization on body weight, hematological traits and blood cholesterol concentration of Nara Chicken. International Journal of Poultry Science, 3 (4): $284-286$

Sena, L., Peti, D. and Nikolova, N. (2013). The effect of physical feed structure on the commercial broiler performance. Macedonian Journal of Animal Science, 3: $207-212$

Shao, Y., Wu, C., Li, J. and Zhao, C. (2009). The effects of different caponization age on growth performance and blood parameters in male Tibetan chicken. Asian Journal of Animal \& Veterinary Advances, 4: 228 - 236

Symeon, G., Mantis, F., and Bizalis, I. (2010). Effect of caponization on growth performance, carcass composition, and meat quality of medium growth broilers. Journal of Poultry Science, 89(7): $1481-1489$

Viola, T. H., Ribeiro, A. M. L. and Penz, Jr. A. M. (2005). Compensatory water consumption of broilers submitted to water restriction from 1 to 21 days of age. Brazilian Journal of Poultry Science, 7 (4): 243 - 245

\section{How to cite this article:}

Bitupon Dutta, Raj Jyoti Deka, Amulya Kumar Gogoi, Bibeka Nanda Saikia, Jog Dev Mahanta, Saurabh Kumar Laskar and Chinmoy Dutta. 2020. Performance of Caponized Local Chicken under Different Production Systems for Small Scale Production in Resource Poor Settings. Int.J.Curr.Microbiol.App.Sci. 9(10): 424-429. doi: https://doi.org/10.20546/ijcmas.2020.910.052 